\title{
エマルのアッカド語の言語的特徴
}

\section{Some Linguistic Features of Emar Akkadian}

池 田 潤

\begin{abstract}
This paper describes some linguistic features of Akkadian administrative texts written with certainty in the city of Emar, i. e. the texts bearing a name of one of the kings of Emar. Emar Akkadian had plural sources which are distinct chronologically and geographically. Thus the resulting linguistic system exhibits archaic/innovative and Babylonian/Assyrian traits side by side. Another salient feature of Emar Akkadian is simplification found in its writing system, morphology and syntax. Besides, a unique formation of primae Alef $\breve{S}$ iprus as well as some unique syllabic/logographic values and lexical items are attested in Emar Akkadian.
\end{abstract}

1. はじめに

エマル（現代のメスケネ）はユーフラテス河中流域に位置する。この地域は

シリア政府が1968年にタブカに和いてユーフラテス・ダムの建設に着手したた めにやがて水没する運命となり，各地で緊急発掘が行われた。メスケネ新市の 発掘は J. Margueron の率いるフランス隊によって1972年から1976年にかけ て行われ，数多くのアッカド語文書と若干のシュメール語・ヒッタイト語・フ リ語文書が発見された。発掘の成果は Beyer 1982に報告されている。

フランス隊が掘り出したアッカド語とシュメール語の文書793点はすべて D. Arnaud によって公刊されている。その他に「ェマル近郊」ないしは「ユーフ ラテス河中流域」出土とされるアッカド語文書が世界各地に点在することが知 られて和り, 筆者の知るかぎりそのらち 200 点がすでに発表されている。これ らのテキストの内容は行政司法文書 (売買契約, 判決, 遺言など), 書簡, 物品 
や人名のリスト，文学テキスト（神話, 知恵文学など), 宗教文書（祭儀文書 や占い文書)，語彙テキスト等の広いジャンルに特よぶ。また，これらのテキス トによってカバーされる年代は紀元前1290～1180年頃と推定されている。

これらのテキストがすべてェマルで書かれたかといらと必ずしもそうではな い。一般にある遺跡から出土した文書がすへてそこで書かれたものとはかぎら ないからである。文学テキストや語彙テキストや祭儀テキストは別の場所で書 かれた「原本」のコピーである可能性が高いし，書簡は発送したものの写し以 外は出土地の外で書かれて出土地に送られたものと考光られる。また，当時の エマルがカルケミシュを通して間接的にヒッタイトの支配下に置かれていたた め，行政司法文書の中にもヒッタイトないしはカルケミシュで書かれてエマル で保管されたものがあったと考光うる。さらに，一般に考觉られているように エマルが「アシュタタの地」の首都であったとすれば，エマルの支配下にあっ た町で書かれた文書が首都に保管される場合もあっただろら。

これらの事情を考慮に入れると, エマル（とその近郊）出土のアッカド語を ひとまとめにしたコーパスはエマルで書かれたアッカド語以外のいわば不純物 を混在させたものとなってしまらことが分かる。このようなコーパスは均質性 を欠いているため, 言語の共時分析の対象としては不適当であるといわざるを 得ない。そこで，本論文では確実にェマルで書かれたアッカド語を「ェマルの アッカド語」と定義し，具体的にはェマルの王の名を記した行政文書をコーパ スとする。

\section{2. 混成語的成り立ち}

エマルの書記たらはアッカド語を母（国）語としていたわけではなく，紀元 前二千年期に古代中東世界の国際共通語の役割を果たしていたアッカド語を外 （国）語として学び運用していたことになる。エマルの書記の教育がどこでな されたかは今後の課題となる問題であるが，彼らのアッカド語習得に括いてメ ソポタミアのアッカド語がターゲットとなっていたことに疑いの余地はない。 ひとくちにメソポタミアのアッカド語と言っても，エマルの書記たちが触れた 可能性のある方言だけでも古期アッカド語 (Old Akkadian), 古期バビロニア 語 (Old Babylonian), 古期アッシリア語 (Old Assyrian), 中期バビロニア 語 (Middle Babylonian), 中期アッシリア語 (Middle Assyrian) があり, 
時代あるいは地域によるバリエーションが見られる。

これらのメソポタミア本土のアッカド語方言とアッカド語圈の周辺部に位置 するエマルのアッカド語とを較べてみると，後者が同時代かそれ以前のメソポ タミア本土のアッカド語方言のいくつかを切り張りしたような体系を有するこ とが分かってくる。言い換えると, エマルのアッカド語は複数のメソポタミア 本土のアッカド語方言に基づき，基になった方言のいずれとも同一ではない新 しい言語体系をなしているのである。

一般に，ある言語圏の周辺部には中央部の言語の古い時代に和ける特徴が残 る場合が多い。これは中央で起こった新しい変化が周辺地域になで到達するの に時間がかかるために起こる現象である。このことはエマルのアッカド語にも 当てはまる。たと光ば，以下のような古い方言の特徴がェマルのアッカド語に は残っている。

1）古期バビロニア語と古期アッシリア語までは。と $A H$ というふたつの音 価が同じ文字で書き表されていたが，中期バビロニア語と中期アッシリア

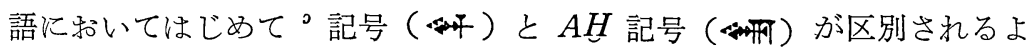
らになった。エマルのアッカド語には同時代のメソポタミアで生じたこの 区別はまだ到達していない。

2）エマルのアッカド語の字音表（シラバリー）も古い時代の特徴を残してい る。エマルのアッカド語では, 古期アッカド語にしかない音価 $d \dot{u}(T U$ 記号), 古期バビロニア語にしかない音価 $g a_{14}$ ? ( $K A$ 記号), $t i_{7}$ ? (TE 記 号), tám ( $U D$ 記号), 古期アッシリア語にしかない音価 $d a ́$ ( $T A$ 記号), $n i_{7}$ ? (NIM 記号) șár (ZUR 記号)，tàm (DIM 記号)，その他中期の方 言にはない音価 $d \grave{\imath}$ ( $T I$ 記号)， $g u_{5}$ ( $K U$ 記号), $\check{s} a_{10}$ ( $S A$ 記号)， tiu ( $D U$ 記号)，wa (PI 記号) が使われている。

3）アッカド語には一般に「broken spelling」と呼ばれる子音と母音，母音 と子音が連接してしまう断絶型の経りが見られ，その多くは声門閉鎖音の 存在（タイプ 1) を示すが, 形態素境界（タイプ 2）や子音の重なり（タ イプ 3）を示す場合もある。古期アッカド語ではタイプ 2 の用法が確認さ れて括り, 古期バビロニア語では 1 と 2 のタイプ, 古期アッシリア語では $1 \sim 3$ の全タイプが見られる。しかし, 中期方言になると broken spelling の用法は事実上タイプ1に限定されてしまう。さエマルのアッカド語に 
は 2 と 3 のイプの broken spelling があることから, これらも古い特 徵とみなすことができよう。

4）二重母音 -iu -の長母音 - $\hat{u}$ - への縮合はメソポタミアでは古期バビロニア 語末期までに完了していた。したがって，an-ni-um（ASJ $127: 35 ）$ と いら例を見るとエマルのアッカド語が $i u>\hat{u}$ といら音韻变化に関しては 古期バビロニア語の段階に留まっていることが分かる。

5）中期方言に見られる音韻変化 - št->-lt-が起こっていない。

6）中期バビロニア語に見られる母音の同化現象 uparris>uperris が起こっ ていない。

7） awātu「ことば，ことがら」という単語は中期方言では母音間の $w$ が $m$ に変化したため amātu となるが，エマルでは awātu のますである。

8）古い方言には-iで終わる construct 形が見られるが，エマルのアッカド 語にも LÚ.MEŠ ši-bu-ti/tì X「Xの長老たち」(AuOrS 1 1:7, 「87; 9 : 19) p ši-im-ti É-ti-šu「彼の家の運命」(AuOr $515: 4 ; R A 772: 4)$ というような例が残っている。

9） anumma「今, ここ」(passim), ašrǐ̌ 「そこに, そこへ」, (passim), bā̌šitu

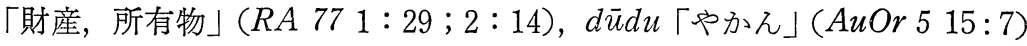
imittu「(槍の類)」(Emar VI 17:5) 等, メソポタミアでは古期バビロ ニア語でしか確認されていない単語が使われている。

しかしながら, 同時にメソポタミアで起こった変化が全く周辺地域に到達し なかったわけではない。エマルのアッカド語では以下の新しい特徵が上で述べ た古い特徴と共存している。

10） mimationの脱落は古期バビロニア語・古期アッシリア語の末期に始をり 中期バビロニア語・中期アッシリア語では historical spelling や +ma と +mi がついた場合を別にすれば完全に消失している。エマルのアッ カド語に叔ける mimation は中期方言と同様 historical spelling や $+m a$ と $+m i$ がついた場合以外では消失している。

11）古期バビロニア語では primae Alef 動詞の G iparras 形抒よびD iparras/ iprus 形は，たと党ば $i-i k-k a-a l \sim i-k a-a l$ と書くのに対し，中期バビロ=

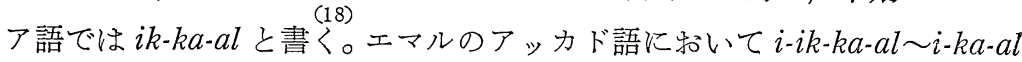
型の綴りが見あたらないのも中期バビロニア語の影響と言えるかもしれな 
W。

12) a ̌s-bu-u「「彼らは留まっている」(Emar VI 17:16) の例から語頭の wが 中期方言と同じく脱落しているのが分かる。

14）母音間の $w$ が $m$ に変化する中期バビロニア語シフトは lam $\hat{u}$ (<law $\hat{u}$, il-mi「それが包囲した」ASJ $127: 30, A u O r S 19: 22)$ といら語彙素 によって確認できる。

15） hurādu「(兵士の一種)」（Emar VI $42: 14)$, balitu「(砂地? )」（Emar $V I 137 ： 22 ， 25 ， 26 ； 138 ： 1 ）$ 等の古い時代のアッカド語には見られない 単語が出てくる。

エマルのアッカド語は明らかにバビロニア方言をベースにしているが，アッ シリアカ言の影響もある程度見られる。

16) 与格の代名詞語尾 +šunūti (バビロニア語では + šunūšri)。

17） 3 人称女性複数斜格語尾 $+a \bar{t} t e(\text { バビロニア語では }+a \bar{t} t i)^{(21)}$

18) 動詞 $s a l \bar{a}^{0} u 「$ 放り投げる」(バビロニア語ではnad $\left.\hat{u}\right)^{(22)}$ そのため，エマルのアッカド語はバビロニア語でもアッシリア語でもない新た な体系をなしている。

\section{3. 文法の単純化}

エマルのアッカド語のもらひとつの大きな特徵として文法の単純化を挙げる ことができる。言らまでもなく，これはエマルのアッカド語が書記たちの母 （国）語でなかったことに起因している。20世紀の人間が国際的なコミュニケー ションのために英語を学んで使用するよらに，エマルの書記たらは当時の古代 中東世界の国際共通語であったアッカド語を外(国)語として習得し運用した。 その結果，日本人が冠詞を落としたり 3 単現の s を無視して英語を運用するこ とがあるように，エマルの書記もメソポタミアのアッカド語を彼らなりに単純 化して使っていた。

ここで注意したいのは，ネイティブのアッカド語ではないからと言って軽視 する必要はないといらことだ。一般にネイティブのことばは「正しく」ノンネ ティブのことばは「正しくない」と思われているためた，ノンネティブのこと ばづかいがネイティブのそれと異なる場合，前者は別個の「言語体系」といら よりは後者の「䛊用」と見られがちである。しかし，第二言語習得について 
W. Klein が次のように述べている通り，別な見方も可能である。

ぞんな言語変種も， いかに未発達のものであれ，変化しやすい成分を別に すると，ある固有の体系性を持つ。そのため，当該変種内に括けるある一 語ないしは一構造が持つはたらきは目標言語に新いてそれらに相当する語 や構造のはたらきだけに由来することはない。(Klein 1986 ：29） これに従い, 我々はエマルのアッカド語が必ずしもメソポタミアのアッカド語 のみに由来しない固有の言語体系を持つといら立場をとり，本節と次節でメソ ポタミアのアッカド語に由来しない体系性を具体的に取りあげていく。

外(国)語を運用する際に起こる単純化にはその場限りの偶発的なるのもある が，それが定着してある特定の集団の中で体系をなしてくる場合もある。エマ ルのアッカド語に执いて後者のタイプに属すると思われるものは次の通りであ る。

19)メソポタミアのアッカド語では dannu「強い, 厳しい」と dannatu「飢 䬺, 苦難」を表意文字で書く場合, 前者は KALA(.GA) 後者は MUNUS. $K A L A . G A$ といら区別がある。そ机に対して，エマルのアッカド語では dannu「強い, 厳しい」も dannatu「飢饉, 苦難」も KALA(.GA) と 書かれる。これは, $K A L A(. G A)$ と $M U N U S . K A L A . G A$ を $K A L A$ $(. G A)$ に一本化する単純化である。

20) ŚU.I.ME ̌́ $t u_{4}$ 「床屋たち」(AuOrS $\left.186: 26\right)$ ， ši-bu-ti「長老たち」 (AuOrS $11: 7$, r87 ; $5: 35,37)$, ši-bu-ti 「長老たち」(AuOrS $19: 19)$, ŠU.I.ME ̌́ -ti-šu-nu「彼らの床屋たち」(AuOrS $186: 4 ， 10)$ 等の例か ら分かるようにメソポタミアのアッカド語では形容詞の複数形に付くは ずの+ütuと + $\bar{t} t i$ が名詞にも使われている。これは名詞と形容詞の区 別を無視する単純化と考学ることができる。

21）メソポタミアのアッカド語では, 名詞に属格代名詞語尾が付くと $i$ 以外の 短母音の格語尾が脱落する (e.g. šumu ルのアッカド語では一部の定型句を除いて短母音の格語尾が脱落しない。 別のことばで言えば，エマルのアッカド語では属格代名詞語尾つきの status constructus が定型句を別にすると status rectus の活用をするとい らことになる。また, 名詞が修飾する場合, 定型句を別にすると X š $a \mathrm{Y}$ 構造 ( $\mathrm{X}$ も $\mathrm{Y}$ も status rectus) がX $\mathrm{Y}$ 構造 ( $\mathrm{X}$ は status constructus, $\mathrm{Y}$ 
は status rectus) よりも圧倒的に多い。これらふたつの現象は, status rectus と status constructus を区別せず status rectus のみで間に合わ せようとする単純化と言ってよいだろう。

22）バビロニア語では $a / \bar{a}$ が同一語中の $e / \bar{e}$ に同化するため, stative 3 人 称女性単数の形態素に $+a t$ (語幹に $e / \bar{e}$ がない場合) $+e t$ (語幹に $e / \bar{e}$ がある場合）といららたつの異形態が生じる。エマルのアッカド語では， 後者の期待される $̌ e b e \overline{e r u}$ の stative 3 人称女性単数形が $̌$ še-eb-ra-at 「それらは壊れている」(Emar VI 256：6）であるため，この異形態の交 替が消失していることが分かる。これは， +at〜 +et といら交替を起こ す異形態を +at に一本化する単純化である。

23）メソポタミアのアッカド語には属格代名詞語尾 1 人称単数に $+y a$ （母音の 後) $+\bar{\imath}$ (子音の後) といら異形態の交替がある。この背後には属格代名 詞語尾が付くと $i$ 以外の短母音の格語尾が脱落するため属格代名詞語尾の 直前が子音になる（e.g. šuma+řsu 21で述べたようにェマルのアッカド語では一部の定型句を除いて短母音の 格語尾が脱落しない。そのため $+i$ は使われず，結果として $+y a 〜+\bar{\imath}$ いら交替を起こす異形態が +yaに一本化されている。

24）メソポタミアのアッカド語では，3人称女性単数の代名詞語尾は属格

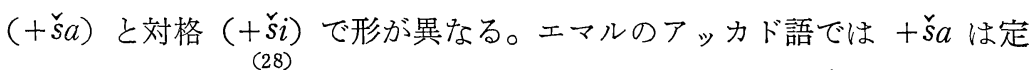
型表現に二度現れるだけで，それ以外では属格にも常に+午iが使われる。 つまり, $+\check{s} a \sim+\check{s} i$ といら異形態の交替を $+\check{s} i$ に一本化する単純化が生 じていることになる。

25）エマルのアッカド語では，書記によって動詞の 3 人称女性形が taprus パ ターンをとる場合と tiprus パターンをとる場合があり，一見したところ 3 人称女性形の接頭辞に $t a+$ と $t i+$ といらふたつの異形態が存在する かのようである。これは，言うまでもなく，tiprus パターンをprus とい ら動詞の語幹に 3 人称女性の接頭辞 $t i+$ がついたものと又なした場合の ことであるが，別の見方も可能である。すなわち，tiprus パターンは $i+$ prus といら性に関しては無標で 3 人称だけを表す形に $t+$ といら女性の 接頭辞がついたものと考光ることもできる。この $t+$ を女性接頭辞， $i+$ を 3 人称接頭辞と捉えるシステムは分析的で効率のよい形態素区分と言う 
ことができる。

26）メソポタミアのアッカド語に和ける precative の形成はバビロニア語と アッシリア語で次のように異なる。表中の $\mathrm{G} と \mathrm{D}$ は語幹, 1 と 3 は人称， 男・女は性を表す。

\begin{tabular}{|c|c|c|c|c|c|c|}
\hline & G 3 男 & G 3 女 & G 1 & D 3 男 & D 3 女 & D 1 \\
\hline バビロニア語 & \multicolumn{2}{|c|}{ liprus } & luprus & liparris & luparris \\
\hline アッシリア語 & liprus & lü taprus & laprus & luparris & lü tuparris & luparris \\
\hline
\end{tabular}

エマルのアッカド語ではバビロニア式でもアッシリア式でもない新たな precative 形成法の萌芽が見光る。lu u-ha-li-iq「彼が根こそぎにするよ らに」(ASJ $14 \mathrm{M}$ ：26）という例はluとひを続けて読めばアッシリア 式のように見光, $\boldsymbol{l u} u$ u-na-ab-bi「彼女が（霊を）呼び出すように」(Emar VI 185:3’) もluとuを続けて読み（動詞自体はバビロニア式の活用 をしているが) precative の形成自体はアッシリア式だと説明することが できないわけではない。しかし, $\boldsymbol{l u}$ - $\boldsymbol{u}$ ú-še-hri-iz-šu「私は彼を結婚させる」 （Emar VI 185：22’）といら経りは明らかに不自然であるため上の三例は lü precative を表す独立小辞として用いることによって precative の形成を単純化する試みの現机と見ることができる。

\section{4. エマルのアッカド語の特異性}

第二節で扱った混成語的成り立ちも第三節で扱った文法の単純化もアッカド 語圈の周辺地域でアッカド語を母語としない書記によって書かれたアッカド語 に広く認められる現象である。このよらなアッカド語を辺境アッカド語 ( $\mathrm{Pe}$ ripheral Akkadian) と呼ぶなら, エマルのアッカド語はボガズキョイやウガ リトやアムルなどのアッカド語と並んで辺境アッカド語のひとつのバリェーシ ョンとして位置づけられるべき言語体系である。そのため, エマルのアッカド 語は数ある辺境アッカド語と多くの特徵を共有するが, エマルのアッカド語に しか見られない特徵もいくつか見つかっている。

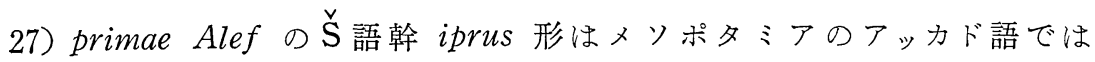
$u \check{s} \bar{a} C_{2} i C_{3}$ パターンをとる（ $C_{2}$ と $C_{3}$ はそれぞれアレフに続く第二・第三 語根を示す) が，li-še-hi-iz「彼ら!が結婚する!（ように）」(RA $771: 36)$ 
预よび ú-še-hni-iz-šu「私は彼を結婚させる」(Emar VI 185：22’）が示す ように，エマルのアッカド語では $u s \bar{s} e C_{2} i C_{3}$ パターンで形成される。

28）エマル独特の音価: $\operatorname{gam}_{x}(G A ́ N$ 記号)。

29）エマル独特の（疑似）表意文字：AH「兄弟」（passim)，GIŠ. KIRI NUMUN「種蒔き済みの耕作地?」（Emar VI $137: 6,8,10,12,17,19$, $58 ; 140: 1,10,14,17)$ ，KI.KÁ「門の岁る場所」(AuOrS $13: 6 ; J C S$

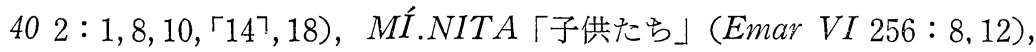
$R U . U P$ 「幅」(passim)。

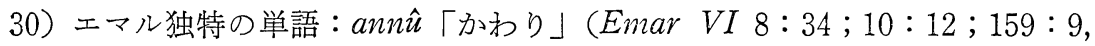
この単語については Ikeda 1992 を参照)， arā̌s 「相続する」(Emar VI 185 : 13' ; RA 77 2:42), Bi-iQ-mi「?」(Emar VI 2:2), KI.erșetu 「宅地?」(passim，この単語については Huehnergard 1991 を参照), ga-mu-rù 「最終的合意?」(AuOrS $155: 23-28)$, hablu「壊れた?」(ASJ $127: 13,18)$, hi-iD-ru「(建物の一種)」(Emar VI 139:8), huhhinnu 「通り」(passim), hu-ku「(パンの一種)」(Emar VI $20: 18)$, hu-ur-ri $\lceil ? 」($ Emar VI 14:1), hu-zu-ra-ni「?」(Emar VI 144:1), NA . KA-ab-ú 「?」(Emar VI 8:15;9:14), KI-Pa-ú 「?」(AuOrS 1 $7: 7$; Emar VI $147: 13$ ), ku-bu-da-e-「所有物?」(AuOr $515: 13,19$, 25), nikaru「他人」(Emar VI $20: 13,31)$, nubbûu「(霊を) 呼び出す」 (Emar VI 185:3' ; RA 77 1:8; 2:12), qa-aZ-ri 「?」(Emar VI $142: 1), L U ́ . s \grave{a}-r a-r i \Gamma$ 見知らぬ者」(RA $772: 19)$, sà-ar-ma-ú $\Gamma($ 長さ の単位)」(JCS $402: 2), N A_{4}$.sikanu「(石の一種)」(Emar VI 17:39; $125: 40), t a$ !-na-ah-la- $\left.{ }^{\ulcorner} t i\right\urcorner$-「遺産?」(AuOrS $\left.135: 10\right), \quad t a-s ̌ i-l[a$ ?-ta? 「立派な?」(Emar VI 42:3), É tugguru「倉庫」(tu-ug-gus-rù Emar VI $144: 1,8,13,15,23,29 \sim$ tu $_{4}$-gu-ru! Emar VI $138: 26,37,40,43,45$ $\sim$ [t]u-gut - ì Emar VI 253:29), ZI-IB-h̆i「?」(Emar VI 2:10; $139: 15)$ 。

注

(1) 第 1 巻と第 2 巻 (Arnaud 1985) には粘土板と断片が書き写してあり，第 3 巻 (Arnaud 1986) 第 4 巻 (Arnaud 1988) には全文書のローマ字転写と翻訳が収めら 
れている。第 3 巻の書評は Durand $(1989,1990)$ にって，また第 4 巻の語彙テキ ストの書評は Civil (1989) によって出されている。

(2) Yoshikawa \& Matsushima 1980, Sigrist 1982, Huehnergard 1983, Meyer \& Wilhelm 1983, Arnaud 1984, Tsukimoto 1984, Arnaud 1987, Beckman 1988, Fales 1988, Tsukimoto 1988, Gonnet \& Malbran-Labat 1989-90, Tsukimoto 1990, Tsukimoto 1991a, Tsukimoto 1991b, Arnaud 1991, Arnaud 1992, Dalley \& Teissier 1992, Tsukimoto 1992a, Tsukimoto 1992b, Sigrist 1993.

(3) 詳しくは山田1994を参照。

（4）同様の見解を有する最近のアッカド語文法に Huehnergard 1989 ( 7 ページ参 照) と Izre'el 1991 ( I : 9-10ページ参照) がある。

（5）エマル王家の系図については，山田1994の34ページを参照。

（6）断片的で言語資料に乏しいものを除いた以下の70点が「エマルのアッカド語」の コーパスである。 $\boldsymbol{R A} 77$ 1=Huehnergard 1983:13-17 (=Tsukimoto 1991: 288-289), RA 77 2=Huehnergard $1983: 17-19$ (=Tsukimoto $1991: 289$ ), Emar VI 1=Arnaud 1986:7-8, Emar VI 2=Arnaud 1986:8-9, Emar VI 3= Arnaud 1986: 9-10, Emar VI 4=Arnaud 1986: 10-11, Emar VI 8=Arnaud 1986 : 15-16, Emar VI 9=Arnaud 1986: 16-17, Emar VI 10=Arnaud 1986 : 18-19, Emar VI 11=Arnaud $1986:$ 19-20, Emar VI 14=A rnaud $1986: 22-23$, Emar VI 17=Arnaud $1986: 26-28$, Emar VI 20=Arnaud $1986: 31-32$, Emar VI 42=Arnaud $1986: 57-58$, Emar VI 94=Arnaud $1986: 106-108$, Emar VI 95=Arnaud 1986: 108, Emar VI 97=Arnaud 1986: 109-110, Emar $\boldsymbol{V I}$ 125= Arnaud 1986 : 133-134, Emar VI 126=Arnaud 1986 : 134-135, Emar VI 137= Arnaud 1986 : 143-146, Emar VI 138=Arnaud $1986: 146-149$, Emar VI 139= Arnaud 1986 : 149-151, Emar VI 140=Arnaud 1986 : 151-152, Emar VI 141= Arnaud 1986 : 153-154, Emar VI 142=Arnaud 1986 : 154-155, Emar VI 144= Arnaud 1986 : 156-158, Emar VI 146=Arnaud $1986:$ 158-160, Emar VI 147= Arnaud 1986 : 160-162, Emar VI 156=Arnaud $1986: 172-173$, Emar VI 157= Arnaud 1986: 173, Emar VI 158=Arnaud $1986: 174-175$, Emar VI 159= Arnaud 1986 : 175-176, Emar VI 180=Arnaud 1986 : 193-194, Emar VI 183= Arnaud 1986: 196, Emar VI 185=Arnaud 1986:197-198, Emar VI 253= Arnaud 1986: 149-150, Emar VI 256=Arnaud $1986: 151-153$, AuOr 5 15= Arnaud 1987 : 235-237, JCS 40 2=Beckman 1988:65-67, (=Tsukimoto 1990 : 185), ASJ $10 \mathrm{D}=$ Tsukimoto 1989 : 163-165, ASJ 121 = Tsukimoto $1990: 177-$ 180, ASJ $\mathbb{1 2} \mathbf{7}=$ Tsukimoto $1990:$ 189-193, ASJ 12 8=Tsukimoto $1990: 193-$ 194, ASJ $1210=$ Tsukimoto $1990:$ 197-198, ASJ 12 16=Tsukimoto $1990: 208-$ 210, AuOrS 1 1=Arnaud 1991:22-23, AuOrS 1 2=Arnaud $1991: 23-24$, AuOrS 1 3=Arnaud $1991: 25-26$, AuOrS 1 4=Arnaud 1991:26-27, AuOrS 
1 5=Arnaud 1991:27-29, AuOrS 1 6=Arnaud 1991:29-30, AuOrS 1 7= Arnaud 1991:31-32, AuOrS 1 8=Arnaud 1991:32-33, AuOrS 1 9=Arnaud $1991: 33-35$, AuOrS 1 10=Arnaud 1991:36-37, AuOrS 1 11=Arnaud 1991 : 37-38, AuOrS 1 12=Arnaud $1991: 39-40$, AuOrS 1 13=Arnaud $1991: 40-41$, AuOrS 1 35=Arnaud $1991: 69-70, \boldsymbol{A u O r S} 1$ 47=Arnaud $1991: 87-88, \boldsymbol{A u} \boldsymbol{O r} \boldsymbol{S}$ 1 54=Arnaud $1991:$ 97-98, AuOrS 1 55=Arnaud $1991: 99-100, \boldsymbol{A u} \boldsymbol{O r} \boldsymbol{S} \mathbf{1} \mathbf{5 9}=$ Arnaud 1991: 104-105, AuOrS 1 60=Arnaud 1991:105-106, AuOrS 1 62= Arnaud 1991: 107-108, AuOrS 1 82=Arnaud 1991:135-136, AuOrS 1 86= Arnaud 1991: 141-142, ASJ $14 \mathrm{M}=$ Tsukimoto 1992b, Iraq 54 4=Dalley \& Teissier 1992: 98-101, Iraq 54 5=Dalley \& Teissier $1992:$ 101-102。なお, 1993年以降に入手可能となった Arnaud 1992 とigrist 1993 は本稿のデータに含 まれていない。

（7）エマルで出土していながらコーパスに入っていない文書，すなわち確実にエマル で書かれた証拠のない文書の中にぱ文字ぬと $A H$ 文字心刑をはっきり区別して いるものがある。

(8) Gelb $1961: 42$ 。

(9) $G A G \S 7 \mathrm{~b}, 23 \mathrm{e}$ 。

(10) Hecker $1968: 31,43,46$ 。

(11) Aro $1955: 20-21$ および Mayer 1971:21 を参照。

（12）ad-din-aš-š [u]「私は彼に与光た」=addin+aššu（Emar VI 180:10), id-in-šu 「彼はそれを与えた」=/iddinšu/(AuOrS $19: 12) 。$

(13) $G A G \S 16$ 。

(14) $G A G \S 64 \mathrm{a}$, Aro $1955: 66$ 。

(15) $G A G \S 63 \mathrm{c}$, Hecker $1968: 96$ 。

(16) Aro $1955: 32$, Mayer $1971: 22$ 。

(17) $G A G \S 23 \mathrm{~d}, 97 \mathrm{c}$, Wilhelm $1971: 285$ 。

(18) Aro $1955: 26-31$ 。

（19）アッシリア方言の影響は目立たない。たとえば，縮合を起こしていない二重母音 の例はあるが，特にアッシリア語の影響と考えなければならないケースはほとんどな い。アッシリア語に特徵的な母音調和はエマルのアッカド語では起こっていない。動 詞の 3 人称女性単数形の接頭辞は $t$ - で始まるが，これはむしろ西セム語の影響と言 えよう。 $s \bar{u} t$ と $s \bar{t} t$ といら独立人称代名詞はアッシリア語的ではあるが, 同様の形が 古期バビロニア語の古い方言にも見られる (Whiting $1987: 9$ 参照)。

（20）i-ba-ga-ar-šu-nu-ti「彼が彼らに権を主張す利る」(AuOrS 186：15，「187), iš-qi-šu-nu-ti「彼が彼らに(灌溉の権利を) 与えた」(AuOrS $186: 30)$, iš-țu-ur-šunu-ti「彼が彼らのために書いた」(AuOrS $186: 11)$ 。Hecker 1968: 77 参照。

(21) a-wa-te-e「ことば」(ASJ 14 M：23)。Mayer 1971：48 および Izre’el 1991 
I: 112-120 参照。

（22）șa-al-ú「彼らが放り出された」(Emar VI 256：9)。CAD Ș：72 参照。

（23）この引用の原文は次の通り。Any language variety, no matter how rudimentary, has apart from some variable components, a certain intrinsic systematicity. Thus the function of any one word or construction without the given variety cannot be derived solely from the function of the corresponding word or construction in the target language.

(24) dannu「強い, 厳しい」一「KALA?(EmarVI $144: 10) \sim K A L A . G A$ (AuOrS 1 $13: 9) \sim K A L A . G A_{14}(A S J 127: 9)$, dannatu「飢饉, 苦難」一KALA-ti (AuOrS 1 $19: 21) \sim K A L A$ (Emar VI $20: 14) \sim K A L A . G A$ (Emar VI 138:11, 24, 41 ; $158: 14) \sim K A L . L A . G I$ (Emar VI $139: 42$ )。

(25) メソポタミアのアッカド語で NAM.KÚR ないしは MUNUS.KÚR と書かれる

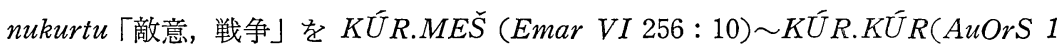
$9: 21)$ と表記するのも同様の単純化と言えるだろう。

（26） $a$-bu-šu「彼の父」(AuOrS 19 :25)，AMA-ma-šu「彼の母」(RA 77 1: 15, 支光の母音 - $a$ - が挿入されているという可能性もある)，AMA-mu-šu-nu「彼らの 母」(RA77 $1: 24), E$-ta-šu「彼の家」(AuOrS $182: 25), E$-tu $135: 15 ; R A 771: 28), \check{S} \bar{A}$-bu-šu「彼の心」(AuOrS 159 : 16 ; JCS $402: 16$ ), ŠA-bu-šu-nu「彼らの心」( ASJ $128: 16 ; 10: 14 ;$ AuOrS $111: 23 ; 12: 14 ; 60$ : 13'; $62: 17$; Emar VI 9:31; $94: 17 ; 140: 15 ; 141:\ulcorner 17\urcorner ; 142: 15)$, šu-ma-šu 「彼の名前」( $A S J 127: 48)$ 。

(27) $G A G \S 10 \mathrm{a}-\mathrm{b}$, Rainer $1966: 83 \mathrm{f}$. 参照。

(28) RU.UP-ša「その幅」(AuOrS $14: 3)$, 「ru’-pu-us-sà「その幅」(Emar VI 3 : 12)。

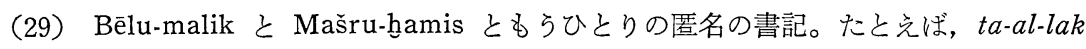
「彼女が行く」(AuOr $515: 23) ，[t] a-a[d-d] i$-in-šu「彼女がそれを売った」(Emar

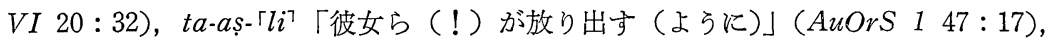
ta-ad-di-na「彼女らが与光る（ように）」(AuOrS $147: 19)$ 。

(30) Imlik-Dagan と Iš-Dagan ともらひとりの匿名の書記。たとえば, ti-im-tù-ta 「彼女たちが死んだ（ら）」（RA $772: 39 ）$,「til-la]-[k]a「彼女が行く」(RA 77 1: 25), ti-il-la-ak「彼女が行く」(RA $772: 20)$, ti-lik「彼女が行く(よらに)」(RA $772:$ 24), ti-im-tì-ut「彼女が死んだ (ら)」(Emar VI $185: 10$ ', 21'；RA 772 :6) $t i$-iš-ku-un「彼女が置く(ように)」(RA $772: 22) 。$

(31) $\operatorname{gam}_{x} !-r i\lceil$ 全 (額)」(Emar VI $9: 29)$ 。

\section{引用文献}

Arnaud, D. 1984

La Syrie du moyen-Euphrate sous le protectorat hittite: l'administration 
d'après trois lettres inédites. Aula Orientalis 2 : 179-188.

Arnaud, D. 1985

Recherches au Pays d'Aštata-Emar VI. Tomes 1-2. Paris.

Arnaud, D. 1986

Recherches au Pays d'Aštata-Emar VI. Tome 3. Paris.

Arnaud, D. 1987

La Syrie du moyen-Euphrate sous le protectorat hittite: contrats de droit privé. Aula Orientalis 5 : 211-241.

Arnaud, D. 1988

Recherches au Pays d'Aštata-Emar VI. Tome 4. Paris.

Arnaud, D. 1991

Textes Syriens de l'âge du bronze récent. Aula Orientalis-Supplementa 1. Barcelona.

Arnaud, D. 1992

Tablettes de genres divers du moyen-Euphrate. Studi Micenei ed Egeo-Anatolici $30: 195-245$.

Aro, J. 1955

Studien zur mittelbabylonischen Grammatik. Studia Orientalia 20. Helsinki.

Beckman, G. 1988

Three Tablets from the Vicinity of Emar. JCS $40: 61-68$.

Beyer, D. (ed). 1982

Meskéné-Emar: Dix ans de travaux 1972-1982. Paris.

$C A D$.

The Assyrian Dictionary of the Oriental Institute of Chicago. Chicago. 1956Civil, M. 1989

The Texts from Meskene-Emar. Aula Orientalis $7: 5-25$.

Dalley S.; Teissier B. 1992

Tablets from the vicinity of Emar and Elsewhere, Iraq $54: 83-111$ (+Plates $\mathrm{X}-\mathrm{XIV}$ ).

Durand, J.-M. 1989

Review of Arnaud 1985, 1986 and 1988. RA $83: 163-191$.

Durand, J.-M. 1990

Review of Arnaud 1985, 1986 and 1988. $R A$ 84:49-85.

Fales, F. M. 1988

Prima dell'alfabeto. Studi e documenti 4. Venezia.

$G A G$

W. von Soden. Grundriss der akkadischen Grammatik. Roma. 1969. 
Gelb, I. J. 1961

Old Akkadian Writing and Grammar. Second edition, revised and enlarged. Materials for the Assyrian Dictionary, 2. Chicago.

Gonnet, H. ; Malbran-Labat, F. 1989-90

Un contrat akkadien avec sceau hittite: AO 28366. Anatolica $16: 1-6$.

Hecker, K. 1968

Grammatik der Kültepe-Texte. Analecta Orientalia 44. Roma.

Huehnergard, J. 1979

The Akkadian Dialects of Carchemish and Ugarit. $\mathrm{PhD}$ dissertation: Harvard University.

Huehnergard, J. 1983

Five Tablets from the Vicinity of Emar. $R A$ $77: 11-43$.

Huehnergard, J. 1989

The Akkadian of Ugarit. Harvard Semitic Studies 34. Atlanta, Georgia.

Huehnergard, J. 1991

More on KI.erșetu at Emar. Nouvelles Assyriologiques Brèves et Utilitaires 1991/2 : 39.

Ikeda, J. 1992

More attestations of ${ }^{\mathrm{c}} N \bar{I}$ in Emar and Munbāqa. Nouvelles Assyriologiques Brèves et Utilitaires 1992/4 : 82-83.

Izre'el, Sh. 1991

Amurru Akkadian: A Linguistic Study. With an Appendix on the History of Amurru by I. Singer. Volume I-II. Harvard Semitic Studies 40-41. Atlanta, Georgia.

Klein W. 1986

Second Language Aquisition. Cambridge Textbooks in Linguistics. Cambridge. Mayer, W. 1971

Untersuchungen zur Grammatik des Mittelassyrischen. AOATS 2. Kevelaer/ Neukirchen-Vluyn.

Meyer, J.-W.; Wilhelm, G. 1983

Eine spätbronzezeitliche Keilschrifturkunde aus Syrien. Damaszener Mitteilungen 1 : 249-61 (plates pp. 58-59).

Reiner, E. 1966

A Linguistic Analysis of Akkadian. Janua Linguarum: Series Practica 21. The Hague.

Sigrist, M. 1982

Miscellanea. JCS 34 : 242-252. 
Sigrist, M. 1993

Seven Emar Tablets. In: A. F. Rainey (ed.), kinattūtu ša därâti: Raphael Kutscher Memorial Volume, Tel Aviv, 165-187.

Tsukimoto, A. 1984

Eine neue Urkunde des Tili-Šarruma, Sohn des Königs von Karkamiš. ASJ $6: 65-74$.

Tsukimoto, A. 1988

Sieben spätbronzezeitliche Urkunden aus Syrien. ASJ $10: 153-189$.

Tsukimoto, A. 1990

Akkadian Tablets in the Hirayama Collection (I). ASJ $12: 177-259$.

Tsukimoto, A. 1991a

Akkadian Tablets in the Hirayama Collection (II), ASJ $13: 275-333$.

Tsukimoto, A. 1991b

Six Texts from the Middle Euphrates Region. ASJ $13: 335-345$.

Tsukimoto, A. 1992a

Akkadian Tablets in the Hirayama Collection (III). ASJ $14: 289-310$.

Tsukimoto, A. 1992b

An Akkadian Field Sale Document Privately Held in Tokyo. ASJ 14 : 311-315.

Whiting, R. M. Jr. 1987

Old Babylonian Letters from Tell Asmar. Assyriological Studies, 22. Chicago. Wilhelm, G. 1971

Eine altbabylonische Graphik im Hुurro-Akkadischen. UF $3: 285-268$. 山田雅道1994

「エマル文書の年代学序説——絶対年代と対照年代」『オリエント』37/1:17-34. 吉川守・松島英子 1980

「東京大学東洋文化研究所所蔵の Bilingual Lexical Tablet」『オリエント』23/2： 1-19. 